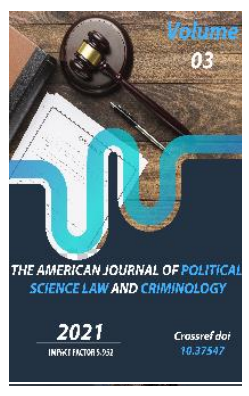

\title{
General Provisions Of Personal And Property Legal Relationships Between Spouses
}

\section{Zulfizar Lochinovna Karimova}

PhD Student, Higher School Of Judges Under The Supreme Judicial Council Of The Republic Of Uzbekistan, Tashkent, Uzbekistan

Journal Website: http://usajournalshub.c om/index,php/tajpslc

Copyright: Original content from this work may be used under the terms of the creative commons attributes 4.0 licence.

\section{ABSTRACT}

The article discusses the general characteristics of personal non-property and property legal relations between spouses, the types of rights and obligations that are included in the range of personal and property relations, the distinctive features of legal relations, the cases when the legal and contractual regime of the property of spouses applies, the types of separate property. In addition, the author proposes to include the concept of "single mother" in Uzbek law, explains this concept, and discusses the foreign practice.

\section{KEYWORDS}

Marriage, spouses, personal non-property relations, property relations, legal regime of the property of spouses, the contractual regime of the property of spouses, premarital property, gratuitously acquired property, individual property, single mother.

\section{INTRODUCTION}

The problems of family life, the problems of legal regulation of family relations in general and their individual groups are traditionally of interest to civil scientists and scientists of 
process [1, pp. 547-552]. The basis of the functioning of the family is marriage - a voluntary union of a man and a woman concluded with the aim of creating a family in compliance with certain rules established by law, which gives rise to mutual personal and property rights and obligations of spouses [2].

Marriage is a union aimed at creating a family on the basis of equality of rights and will of a man and a woman and mutual rights and obligations of spouses [3, p. 11]. Marriage is not only a union between a man and a woman, but also a legal fact. From the moment of marriage, both of them acquire the status of spouses. Each spouse becomes the owner of the rights and obligations provided for by the rules of family law.

\section{THE MAIN FINDINGS AND RESULTS}

Relationships between spouses are complex and varied. During, as a rule, a rather long life together, the spouses enter into a variety of relationships with each other. Many of them are not regulated by law at all. However, there are also those that are subject to legal regulation. Among them are property and some personal non-property relations.

The Family Code of the Republic of Uzbekistan explicitly states that from the moment of registration of marriage in the civil registry offices, persons who have entered into marriage become spouses, and from that time the rights and obligations of spouses arise between them. That is, the fact of marriage gives rise to the emergence of rights and obligations. These rights and responsibilities fall into two groups:

- Personal non-property legal relationship (personal rights and obligations);
- Property legal relations (property rights and obligations).

The rights and obligations of spouses - both personal and property - exist within the framework of a single marital relationship [4]. And they act not as two independent legal relationships (personal and property), but as a marriage relationship with a set of personal and property rights among spouses (or among parents and children) as subjects of each legal relationship. In this case, the spousal (marriage) legal relationship arises in connection with a single act - the conclusion of marriage. It ends, like the entire set of rights and obligations, with the termination of marriage. Spouses cannot get married, take on only one right (for example, personal) and negotiate the refusal of others (for example, property). Such a waiver is invalid. They simultaneously accept all the rights and obligations that are included in the content of the legal relationship [5, p. 34].

Personal rights include those rights that are enshrined in general regulatory legal acts: in the Constitution of the Republic of Uzbekistan and other acts. In particular, Article 46 of the Basic Law provides that women and men have equal rights. The Family Code, developing the provision of the Constitution of the Republic of Uzbekistan, indicates in Article 19 that spouses enjoy equal rights in the family and bear equal responsibilities. At the same time, marital relations presuppose the coordination of the interests of the spouses.

The personal rights of spouses include:

- The right to choose a family name by spouses;

- The right for the spouses to decide the issues of raising children and family life; 
- The spouses' right to choose an occupation, profession and place of residence;

- The right to the upbringing and education of a child;

- The right to motherhood, fatherhood and others.

However, this list is not in any way restrictive and other rights may arise during the period of marriage.

Matters of family life are decided by spouses jointly, based on the principle of equality of spouses. Spouses are obliged to build their relations in the family on the basis of mutual respect and mutual assistance, to promote the well-being of the family, and to take care of the well-being and development of their children. These are declarative norms, since for the most part personal relations between spouses are governed by moral norms and customs.

The personal rights and obligations of spouses cannot be changed or terminated by an agreement between the spouses; they cannot be the subject of a marriage contract $[6, p .35]$.

The spouses' personal responsibilities include:

- To promote the well-being and strengthening of the family;

- To take care of the welfare and development of their children.

- Build their relationships in the family on the basis of mutual respect and mutual assistance;

- Take care of health promotion, physical, mental and moral development of all family members;

- Reckon with the opinion of the spouse and other family members when solving various family issues;
- Not create obstacles to the spouse when choosing his surname when entering into marriage;

- Not to interfere with the spouse in choosing his occupation, profession, place of stay and residence;

- Not to violate the rights, freedoms and legally protected interests of other family members.

Unlike personal non-property legal relations between spouses, property legal relations lend themselves to legal regulation much better. Property legal relations of spouses refer to relations arising from a marriage registered in accordance with the established procedure in state bodies.

In accordance with article 6 of the Family Code of the Republic of Uzbekistan, civil legislation is applied to property and personal non-property relations between family members that are not regulated by family legislation insofar as it does not contradict the essence of family relations. Consequently, the norms of family law regulating the property relations of spouses are supplemented by norms of civil law. Thus, all general norms of the Civil Code of the Republic of Uzbekistan on property in general and on joint property in particular are applicable to the property relations of spouses. The procedure and grounds for concluding, changing, terminating a marriage contract and invalidating a marriage contract, along with the norms of the Family Code of the Republic of Uzbekistan, are governed by the relevant norms of the Civil Code of the Republic of Uzbekistan on transactions and contracts. The norms of family law governing the property relations of spouses are special in relation to the corresponding norms of civil law. They, firstly, detail the provisions of the Civil Code of 
the Republic of Uzbekistan, and secondly, they establish certain exceptions to the general rules provided for by civil legislation, related to the specifics of family relations, which are personally confidential.

Based on the foregoing, the following definition can be given: "Property legal relations of spouses are social relations regulated by the norms of family and civil law that develop between spouses regarding property acquired in marriage and mutual provision of maintenance."

Property relations between spouses, regulated by the norms of family law (property legal relations), are traditionally divided into two main groups:

1. Relations with regard to common matrimonial property (that is, property acquired by spouses during marriage);

2. Relations regarding the mutual material content (alimony obligations).

The state establishes legal regimes for the property of spouses, which make it possible to achieve the satisfaction of their legitimate interests in the regulation of any property relations. According to the Family Code of the Republic of Uzbekistan, there are two types of property regime for spouses: legal (Articles 2328 Family Code of the Republic of Uzbekistan) and contractual (Articles 29-36 Family Code of the Republic of Uzbekistan).

The legal regime of the spouses' property applies in all cases where a marriage contract has not been concluded between the spouses. The legal regime presupposes that the property acquired by spouses during marriage, as well as acquired before the registration of the marriage at the common funds of the future spouses, is their common joint property, unless otherwise provided by law or the marriage contract. Spouses have equal rights to own, use and dispose of the property that is their common joint property. The contractual regime assumes that the property rights and obligations of the spouses during marriage and in the event of its dissolution are determined by agreement of the parties, in which they have the right to deviate from the legal regime of the spouses' property.

The property belonging to each of the spouses (separate property) can be divided into three parts.

First, premarital property, i.e. property acquired before marriage. It is important to note that it is also not common joint property acquired, although during marriage, but at the personal expense of one of the spouses, which belonged to him before marriage.

Secondly, property acquired free of charge, i.e. property acquired during marriage under gratuitous civil transactions. The law includes inheritance, a donation agreement, as well as the acquisition of residential premises by way of privatization to such transactions. State and other awards also apply to separate property.

Thirdly, individual property, i.e. things for individual use, including those acquired at the expense of common funds. Article 26 of the Investigative Committee of the Republic of Uzbekistan names only clothing and footwear, but does not provide an exhaustive list of such property. At the same time, it is obvious that such things should include underwear, personal hygiene items, and other property, normally intended for use by only one person. The only exception to this rule is property related to jewelry and other luxury goods. 
Property relations governed by family law include not only rights, but also obligations. In order to determine which particular spouse will be responsible for the undertaken obligation, it is necessary:

- To set the time of the conclusion of the obligation, i.e. before the registration of marriage or at the time of being in it;

- $\quad$ Find out the purpose of the obligation;

- Determine the amount of damage caused by non-compliance with the obligation.

Personal obligations include those that are aimed at meeting the individual needs of one of them, and general obligations are those of prisoners in order to cover the needs of the whole family [7].

Thus, the following distinctive features of legal relations between spouses can be distinguished:

- The rights and obligations of the spouses arise from the moment the marriage is registered with the civil registry offices;

- All rights and obligations of spouses are divided into two groups: personal and property;

- Personal rights of spouses are inalienable from their bearer, as well as by the will of their owner;

- The personal rights of the spouses cannot be the subject of any transactions and do not have a monetary or other material equivalent;

- The personal rights of the spouses terminate with the termination of the marriage, and disputes related to property rights arise in most cases after the termination of the marriage;

- The property of the spouses may include not only material objects and legal claims, but also the obligations of the spouses (debts).

In the Republic of Uzbekistan, as in many developed countries, the family as a social and cultural institution is undergoing profound changes, which are manifested, first of all, in a decrease in the number of marriages; an increase in the number of divorces and the formation of families of estranged spouses.

Referring to the statistics of divorces in 2020, 28233 divorces were registered, which is 3156 , or $20 \%$ less than in 2019 (31 389) [8]. The authorities consider divorce to be one of the foundations of the disintegration of moral values and family foundations and associate it with an increase in crime, including child and female migration, unemployment, an increase in the number of families without financial support, an increase in lawsuits for alimony, etc.

Every year in Uzbekistan, after divorce, hundreds of thousands of women remain single, some of whom acquire the status of single mothers. Thus, according to research carried out by the Mahalla Va Oila Research Institute under the Ministry for Support of Mahalla and Family, the number of single mothers throughout the country is 5459. At all times, single mothers were one of the most vulnerable groups of the population. After all, a woman who, for one reason or another, was left alone with a child in her arms, needs not only to raise a child - she needs to provide him with everything he needs, which requires a lot of physical and material costs. And if a woman does not have any outside help in the form of alimony, social benefits, etc., then this is very difficult to do. 
In the current legislative and regulatory legal acts of the Republic of Uzbekistan, there is no concept of "single mother", but, nevertheless, we can talk about the assistance that is provided by the state to socially vulnerable segments of the population. Low-income families registered in the Unified Register of Social Protection are exempted from parental fees in kindergartens, for renting school textbooks, for studying in music and art schools and Barkamol Avlod centers. In addition, according to article 180 of the Tax Code of the Republic of Uzbekistan, tax benefits are provided only for single mothers with two or more children under 16 years of age [9, p. 187]. However, despite the benefits provided, the status of single mothers has not been fully regulated.

\section{CONCLUSION}

Studying the legislation of other foreign countries, in some of them you can find the definition of the concept of "single mother". Thus, according to Article 18 of the Law of Ukraine "On State Assistance to Families with Children", the status of single mothers in Ukraine is granted to women who are not officially married, have children who have not yet reached the age of majority and are supported by their mothers. In the birth certificate of children, there must be no record about the father, or it was entered according to the mother's words by authorized employees of the "civil registry" in the established legal order. According to the legislation of the Republic of Belarus, single mothers include women who are not married and have children, in the birth certificate of which the father is recorded in the prescribed manner at the direction of the mother, as well as widows who have not remarried and are raising minor children. In Germany, single mother status is granted to a woman who lives separately from her husband. That is, we know about dad, and he can even pay child support, she just lives alone with the child.

Based on the foregoing, it is proposed to include the concept of "single mother" in the legislation of the Republic of Uzbekistan, indicate who has the right to receive this status, which body provides this status, what benefits are provided, etc.

\section{REFERENCES}

1. Esanova Z.N. (2020). Judicial consideration of adoption cases in Uzbekistan: discussions and proposals. Bulletin of the Tajik State University of Law, Business and Politics. Humanities Series. - 2009. - №. 1. Esanova Z.N. Consideration of adoption cases in civil courts (on the example of the legislation of the Republic of Uzbekistan) // Problems of theory and practice of modern science. - pp. 547-552. (Эсанова 3. Н. Судебное рассмотрение дел об усыновлении в Узбекистане: дискуссии и предложения //Вестник Таджикского государственного университета права, бизнеса и политики. Серия гуманитарных наук. - 2009. - №. 1.; Эсанова 3. Н. Рассмотрение дел об усыновлении в гражданских судах (на примере законодательства Республики Узбекистан) //Проблемы теории и практики современной науки. - 2020. - с. 547-552.)

2. https://foxford.ru/wiki/obschestvoznanie/ pravovye-osnovy-semi-i-braka

3. X.Yodgorov, I.Kosimov, A.Salaev. (2017). Judicial practice in disputes arising from family and marital relations is a practical guide. - Tashkent. - р. 11 (Оила ва никох 
The American Journal of Political Science Law and Criminology (ISSN - 2693-0803)

Published: April 27, 2021 | Pages: 55-61

Doi: https://doi.org/10.37547/tajpslc/Volumeo3lssue04-09

муносабатларидан келиб чиқувчи низолар бўйича суд амалиёти - амалий қўлланма. Х.Ёдгоров, И.Косимов, А.Салаев. Тошкент 2017, с.11)

4. Esanova Z. (2009). The concept and types of disputes related to the upbringing of children, the causes of their occurrence, measures to prevent them and ways of solving. Scientific notes of the Khujand State University. Academician B. Gafurov. Humanitarian sciences. No. 3. (Эсанова 3. Понятие и виды споров, связанных с воспитанием детей, причины их возникновения, меры их предотвращения $и$ пути решения //Ученые записки Худжандского государственного университета им. академика Б. Гафурова. Гуманитарные науки. - 2009. - №. 3.)

5. Karakhodzhaeva D. (2016). Family Law. Textbook for professional colleges / D. Karakhodzhaeva. - Tashkent: "ILM ZIYO”. - p. 34 (Караходжаева А. Семейное право. Учебное пособие для профессиональных колледжей / А. Караходжаева. - T.: «ILM ZIYO», 2016. - c.34)

6. Family law of the Russian Federation: Textbook. South-Russian State Polytechnic University. - Novocherkassk: YURSTU. 2010. - p. 35 (Семейное право Российской Федерации: учебное пособие. / Юж.Рос.гос. техн. ун-т. - Новочеркасск: ЮРГТУ, 2010. - c.35)

7. Muratova S.A. (1999). Family Law: Schemes and Comments: Textbook. Allowance. Moscow: Jurisprudence. (Electronic library). (Муратова С.А. Семейное право: Схемы и комментарии: Учебн. пособие. М.: Юриспруденция, 1999. (Электронная библиотека).)
8. https://stat.uz/uz/rasmiystatistika/demography-2

9. Tax Code of the Republic of Uzbekistan: Official publication. Ministry of Justice of the Republic of Uzbekistan. - Tashkent: “Adolat”. 2012. - p. 187 (Налоговый кодекс Республики Узбекистан: Официальное издание. Министерство Юстиции Республики Узбекистан. - Т.: «Адолат», 2012 г. - c.187) 